\title{
Response of Some Peanut Genotypes to Phosphorus Fertilization Levels Under New Valley Conditions
}

\author{
Abd El-Monem, A.M.A. ${ }^{1}$ and M.T. Said ${ }^{2}$ \\ ${ }^{1}$ Agronomy Department, Faculty of Agriculture, New Valley Branch, Assiut University. Assiut, \\ Egypt. \\ ${ }^{2}$ Agronomy Department, Faculty of Agriculture, Assiut University, Assiut, Egypt. \\ Received on: 19/2/2018 \\ Accepted for publication on: 6/3/2018
}

\begin{abstract}
A field experiment was conducted at Faculty of Agriculture Farm, Assiut University, New Valley branch during 2015 and 2016 summer season to study the response of five peanut genotypes to phosphorus fertilization levels. This experiment was laid out in arandomized complete block design (RCBD) in a split plot arrangement with three replications. Phosphorus levels $(\mathrm{P})$ were distributed randomly on the main plot and peanut genotypes at sub plot. The obtained result show that peanut plants fertilized with $45 \mathrm{~kg}$ fed. ${ }^{-1} \mathrm{P}_{2} \mathrm{O}_{5}$ significantly gained the highest mean values of most studied traits in the two growing seasons. Furthermore, peanut genotypes had a significant effect on most studied traits in both seasons. Thus, L35 peanut genotype surpassed the others tested genotypes in most studied traits in both seasons. Moreover, the highest mean values of seed yield and oil yields were obtained from $45 \mathrm{~kg}$ fed. ${ }^{-1} \mathrm{P}_{2} \mathrm{O}_{5}$ and $\mathrm{L} 35$ peanut genotype surpassed all other genotypes in seed and oil yields in both seasons.
\end{abstract}

Keywords: Peanut Genotypes, Phosphorus Fertilization, New Valley Conditions

\section{Introduction}

Peanut (Arachis hypogaea L.) is one of the major source of edible oil and the third most fundamental source of protein (Sorrensen et al., 2004; Taru et al., 2008). The cultivated area of peanut in Egypt during 2016 season was about 58000 ha with the total yield production of 190865 tons (FAO, 2016). Therefore, we need to improve peanut production, especially in desert area, throw new genotypes, sowing methods and organo-mineral fertilizers. Many investigators found significant variation between peanut genotypes in growth, yield, yield components and quality due genetic variability and interaction with environmental condition (Meena et al., 2014; Mahrous et al., 2015; Sarkees, 2015 and El-Far et al., 2016).
Nutrient deficiency, especially phosphorus has been reported as a major abiotic factors limiting groundnut production especially in Africa where production is characterized by low fertilizer inputs (Bationo et al., 2006; Vara Prasad et al., 2009).

Phosphorus is one of major essential nutrient for crop growth, yield and quality. There is a higher requirement for Phosphorus in nodulation legumes compared to nonnodulation crops as it plays a significant role in nodule formation and fixation of nitrogen (Brady and Weil, 2002). Due to the important role played by $\mathrm{P}$ in the physiological processes of plants, adequate supply of $\mathrm{P}$ to soil deficient in this nutrient enhances groundnut yield and its income. Furthermore, phosphorus is an essential constituent of nucleic acids 
and stimulates root growth as well as increase nodule activity in plant. Also, phosphorus is essentially required for healthy growth with efficient root system and profuse nodulation which, in turn can affect the $\mathrm{N}_{2}$ fixation potential (Kwari, 2005). Deficiency of phosphorus due to inavailability of soluble phosphate in soil solution is considered as a limiting factor in plant nutrition (Uma and Sathiyavani, 2012). Phosphorus fertilization affected vegetative growth and biomass of groundnut asit is vital for the growth and yield (Kamara et al., 2011a).

This investigation was conducted to study the response of some peanuts genotypes to different levels of phosphorus fertilization under New Valley Governorate conditions.

\section{Materials and Methods}

The investigation was conducted at Faculty of Agriculture
Farm, Assiut University, New Valley branch during 2015 and 2016 summer season to study the response of some peanut genotypes i.e., NC, L3, L10, L35 and L27R which introduced from America, Brazil, Malawi, China and Israel, respectively to phosphorus fertilization levels i.e., 15,30 and $45 \mathrm{~kg}$ $\mathrm{fed}^{-1}$. The previous peanut genotypes belong to semi-erect types. This experiment was carried out using randomized complete block design (RCBD) in a split plot arrangement with three replications. Phosphorus levels were distributed randomly on the main plot and peanut genotypes at sub plot. Sub plot included four rows, a single row was $3 \mathrm{~m}$ long and spaced $0.50 \mathrm{~cm}$ apart with $0.25 \mathrm{~cm}$ (plot size $6 \mathrm{~m}^{2}$ ). The physical and chemical analyses of soil field trials are presented in Table 1.

Table 1. Analysis of soil field experiment

\begin{tabular}{|c|c|c|c|c|c|c|c|c|c|c|c|c|}
\hline \multirow{3}{*}{ pH } & \multirow{3}{*}{$\underset{\left(\mathbf{d s ~ m}^{-1}\right)}{E C}$} & \multirow{3}{*}{$\underset{\left(\mathrm{g} \mathrm{kg}^{-1}\right)}{\mathbf{O M}}$} & \multicolumn{6}{|c|}{ Nutrient content, $\mathrm{mg} \mathrm{kg}^{-1}$} & \multirow{2}{*}{\multicolumn{3}{|c|}{ Particle size distribution }} & \multirow{3}{*}{$\begin{array}{c}\text { Textural } \\
\text { class }\end{array}$} \\
\hline & & & \multicolumn{2}{|c|}{$\mathrm{N}$} & \multicolumn{2}{|c|}{$\mathrm{P}$} & & & & & \\
\hline & & & Total & available & Total & Available & Total & Available & Clay & Silt & Sand & \\
\hline $\begin{array}{c}7.97 \\
\pm 0.06\end{array}$ & $\begin{array}{c}0.26 \\
\pm 0.04\end{array}$ & $\begin{array}{r}1.10 \\
\pm 0.2\end{array}$ & $\begin{array}{c}159.60 \\
\pm 11.30\end{array}$ & $\begin{array}{r}29.20 \\
\pm 2.45\end{array}$ & $\begin{array}{l}62.30 \\
\pm 6.74\end{array}$ & $\begin{array}{c}4.66 \\
\pm 0.92\end{array}$ & $\begin{array}{c}243.0 \\
\pm 13.23 \\
\end{array}$ & $\begin{array}{c}154.00 \\
\pm 8.76\end{array}$ & $\begin{array}{c}6.84 \\
\pm 0.48\end{array}$ & $\begin{array}{l}11.24 \\
\pm 0.47\end{array}$ & $\begin{array}{l}81.92 \\
\pm 0.31\end{array}$ & Sandy \\
\hline
\end{tabular}

Mono calcium super phosphate $\left(15 \% \mathrm{P}_{2} \mathrm{O}_{5}\right)$ used as a source of phosphorus and added before planting. Planting date was at April, 20 and 25 in 2015 and 2016 season, respectively. All other cultural practices were carried out as recommended for peanut production.

At harvest time, five guarded plants were taken randomly from each subplot for measuring plant height $(\mathrm{cm})$, number of branches plant $^{-1}$, number of pods plant ${ }^{-1}$, pods weight plant $^{-1}(\mathrm{~g})$, seed number plant ${ }^{-}$ ${ }^{1}$, seeds weight plant $^{-1}(\mathrm{~g})$ and 100- seed weight were determined. Pods yield was determined at harvest on plot basis. Seed oil content was determined by Soxhlet apparatus according to A.O.A.C. (1995). Multiplication of oil percentage by seed yield in $\mathrm{kg} \mathrm{fed}^{-1}$ to obtain oil yield in $\mathrm{kg} \mathrm{fed}^{-1}$.

The collected data were analyzed using analysis of variance (ANOVA) with SAS Statistical Software Package (v.9.2, 2008). Means were compared by revised Least significant difference (RLSD) at $5 \%$ 
level of significant (Gomez and Gomez, 1984).

\section{Results and Discussion Vegetative traits:}

Data presented in Table 2 reveal that the phosphorus levels had a significant effect on plant height and number of branches plant ${ }^{-1}$ traits in both seasons. Thus, the tallest peanut plants (37.11 and $37.18 \mathrm{~cm}$ in the first and second seasons, respectively) and the highest mean values of branches number plant $^{-1}$ (9.91 and 9.87 in the first and second seasons, respectively) were obtained from peanut plants fertilized by $45 \mathrm{~kg} \mathrm{P}_{2} \mathrm{O}_{5}$ fed. ${ }^{1}$ in both seasons while, the lowest mean values of mentioned traits were registered for the lowest phosphorus fertilization level $\left(15 \mathrm{~kg} \mathrm{P}_{2} \mathrm{O}_{5}\right.$ fed. $\left.^{-1}\right)$. Phosphorus is essentially required for healthy growth with efficient root system and profuse nodulation which, in turn can affect the $\mathrm{N}_{2}$-fixation potential (Kwari, 2005). Similar trend was obtained by Uma and Sathiyavani (2012) and Kamara et al. (2011b).

Here too, the studied peanut genotypes had a significant influence on plant height in the first season, meanwhile number of branches plant ${ }^{1}$ was affected significantly in the two growing seasons (Table 2). L3 genotypes surpassed the other tested genotypes and produced the maximum mean values of plant height $(35.52$ and $35.74 \mathrm{~cm}$ in the first and second seasons, respectively) while, L27R gave the highest mean values of branches number plant ${ }^{-1}$ (9.67 and 9.78 in the first and second season, respectively). This is may be due to the genetic variation among studied genotypes and their interaction with environmental factors. These findings are in agreement with those obtained by Meena et al. (2014), Mahrous et al. (2015), Sarkees (2015) and El-Far et al. (2016).

Furthermore, the interaction between phosphorus fertilization and genotypes had a significant influence on plant height in the first season only. While the effect of this interaction on plant height in the second season and number of branches in both seasons not significant. Thus the tallest peanut plants $(39.11 \mathrm{~cm})$ in the first season where obtained from L3peanut genotype fertilized by 45 $\mathrm{Kg} / \mathrm{Fed} . \mathrm{P}_{2} \mathrm{O}_{5}$.

\section{Yield components traits:}

Number of pods plant ${ }^{-1}$, pods weight plant ${ }^{-1}$, number of seed plant ${ }^{-1}$ and seed weight plant ${ }^{-1}$ traits were affected significantly by phosphorus fertilization levels in both seasons (Table 3). Peanut plants fertilized with $45 \mathrm{~kg} / \mathrm{fed} . \mathrm{P}_{2} \mathrm{O}_{5}$ produce the maximum mean values in this respect, which were $52.7,81.5 \mathrm{~g}, 91.3$ and $55.5 \mathrm{~g}$ of number of pods plant ${ }^{-1}$, pods weight plant $^{-1}$, number of seed plant $^{-1}$ and seed weight plant ${ }^{-1}$, respectively, in the first season being, $54.4,86.3 \mathrm{~g}, 88.8$ and 57.3 in the same order in the second season. This is to be expected since the same high phosphorus fertilization levels produced the highest mean values with regard to plant height and number of branches per plant and consequently produced the highest mean values of yield components traits. Similar trend was obtained by Uma and Sathiyavani (2012) and Kamara et al. (2011b).

Concerning genotypes effect in this respect, data illustrated in Table 3 
focus that the all studied yield components traits were significantly affected by tested genotypes in the first season only except number of pods plant $^{-1}$ and seed index traits which was reacted significantly in both seasons. L35 surpassed all genotype in this respect and registered $72.3 \mathrm{~g}$, 78.2 , and $50.0 \mathrm{~g}$ of pods weight plant $^{-1}$, number of seed plant ${ }^{-1}$ and seed weight plant $^{-1}$, respectively as well as the heights mean values of number of pods plant ${ }^{-1}$ and seed index (49.4 and 65.1 in the first season, became higher for both traits (52.1 and $69.4 \mathrm{~g}$ ) in the second season. This is may be due to the genetic variation between studied genotypes and their interaction with environmental factors. These findings are in agreement with those obtained by Meena et al. (2014), Mahrous et al.(2015), Sarkees (2015) and El-Far et al.(2016).

Regarding the interaction effect, data exhibited in Table 3 revel that pod weight per plant, seed number per plant and seed weight per plant were affected significantly by the interaction between phosphorus fertilization levels and peanut genotypes in the first season only. Thus, planting L35 peanut genotype subjected to 45 $\mathrm{kg} /$ fed. $\mathrm{P}_{2} \mathrm{O}_{5}$ recorded the maximum mean values of previous treats, which were $104.4 \mathrm{~g}, 117.2$ and $71.2 \mathrm{~g}$ respectively. Moreover, seed index was significantly affected in the second season only. On the other hand, number of pods plant ${ }^{-1}$ reacted significantly to the interaction between phosphorus fertilization levels and peanut genotypes in both seasons. The highest mean values of number of pods plant ${ }^{-1}$ (70.0 and 69.0 in the first and second season respectively) were obtained from L35 peanut plants fertilized with $45 \mathrm{~kg} /$ fed. $\mathrm{P}_{2} \mathrm{O}_{5}$ while, the heaviest seed index (68.3 and 73.2 in the first and second season respectively) were obtained from L35 peanut plants fertilized with 15 $\mathrm{kg} /$ fed. $\mathrm{P}_{2} \mathrm{O}_{5}$.

\section{Pods and seed yields:}

The influence of phosphorus fertilization level on pods and seed yields of peanut were significant in both seasons (Table 4). Increasing phosphorus fertilization levels from 15 to $45 \mathrm{~kg} /$ fed $\mathrm{P}_{2} \mathrm{O}_{2}$ increased pods and seed yields by the rate of 73.3 and $88.5 \%$, respectively in the first season being 83.0 and $95.3 \%$ in the second season in the same order. The same trend was observed with regard to yield components traits. Similar trend was obtained by Uma and Sathiyavani (2012) and Kamara et al. (2011a).

Studied peanut genotypes varied significantly with regard to pods and seed yields in both seasons. L35 genotype produced the highest mean values in this respect, which, were 1418 and $910 \mathrm{~kg} / \mathrm{fed}$. of pods and seed yields in the first season being 1353 and $929 \mathrm{~kg} / \mathrm{fed}$ in the second season in the same order. This is to be logic since the same peanut genotype (L35) registered the maximum mean values with regard to most yield components traits as mentioned before and consequently produced the highest mean values of pods and seed yields. These findings are in agreement with those obtained by Meena et al. (2014), Mahrous et al.(2015), Sarkees (2015) and El-Far et al. (2016).

Concerning the interaction effect, data exhibited in Table 4 reveal 
that the interaction between phosphorus fertilization levels and peanut genotypes had a non- significant effect on pods and seed yields in the two growing seasons except pods yield in the first season. Cultivated L35 peanut genotype and fertilized it by $45 \mathrm{~kg} /$ fed. $\mathrm{P}_{2} \mathrm{O}_{5}$ gained the highest mean value of pods yield in the first season (1945 kg/ fed.). This is to be logicas the same trend was observed with regard to most yield components traits.

\section{Oil percentage and oil yield:}

Illustrated data in Table 4 note that the tested phosphorus fertilization levels had a significant influence on oil percent in the first season only, while; the effect was significant on oil yield in both seasons. Peanut plants, which fertilized with 45 $\mathrm{kg} /$ fed. $\mathrm{P}_{2} \mathrm{O}_{5}$ produced the highest mean values of oil percent $(47.8 \%)$ and oil yield $(455 \mathrm{~kg} / \mathrm{fed})$ in the first season, being $481 \mathrm{~kg} /$ fed of oil yield in the second season. This is to be logic since the same phosphorus fertilization level gained the highest mean values with regard to seed yield and consequently gained the maximum oil yield. Similar trend was obtained by Uma and Sathiyavani (2012) and Kamara et al.(2011b).

Regarding peanut genotypes, the presented data in Table 4 focus that the tested peanut genotypes had a significant effect on oil percentage in the second season only whoever, the effect was significant on oil yield in both seasons. L27R peanut genotype surpassed the others tested genotypes with regard to seed oil percentage in the second season and recorded $47 \%$ oil percentage. On the other hand, L35 peanut genotypes produced the maximum oil yield (416 and $414 \mathrm{~kg}$ / fed in the first and second seasons, respectively). This to be due to the superiority of L35 peanut genotype with regard to seed yield as mentioned before. These findings are in a good line with those obtained by Meena et al. (2014), Mahrous et al. (2015), Sarkees (2015) and El-Far et al.(2016).

Furthermore, the interaction did not achieve any significant effect in this respect except the effect of interaction on oil percentage in the second season, which was significant. The maximum seed oil content in the second season was $48.5 \%$, which was achieved from L27R peanut genotype subjected to $30 \mathrm{~kg} /$ fed of $\mathrm{P}_{2} \mathrm{O}_{5}$ (Table 4).

\section{Conclusion}

From the obtained results, the investigators could be recommending by planting L35 peanut genotype and fertilized it with $45 \mathrm{~kg}$ fed. ${ }^{-1} \mathrm{P}_{2} \mathrm{O}_{5}$ to obtained the highest values of seed and oil yield under the same conditions.

\section{References}

A.O.A.C. (1995). Association of Official Analytical Chemists. Official methods of analysis, $16^{\text {th }} E d$. AOAC International, Washington, D.C., USA.

Adinya, I. B., Enun, E. E. and Ijoma, J. U. (2010). Exploring profitability potentials in groundnut production through agroforestry practices: a case study in Nigeria. Journal of Animal and Plant Sciences, 20(2): $123-131$.

Bationo, A., Hattemink A., Lungu, O., Naimi, M., Okoth, P., Smaling, E. and Thiombiano, L. (Ed) (2006). African Soils: Their Productivity and Profitability of Fertilizer Use. 
African Fertilizer Submit, Abuja, Nigeria.39pp.

Brady, N. C. and Weil, R. R. (2002). The Nature and Properties of Soils. (13 ${ }^{\text {th }}$ Ed.), Pearson Education Pvt. Ltd., Indian Branch, Singapore. $311 \mathrm{pp}$.

El- Far, I.A., E.A. Ali, W.A. El-Sawy and A.H. Mohamed (2016). Evaluation of Some Peanut Genotypes under Two Planting Methods and Different Fertilization Levels. Assiut J. Agric. Sci., (47):(6-2) (311-324).

FAO (2014). Faostat, fao.org/download $/ \mathrm{Q} / \mathrm{QC} / \mathrm{E}$.

Gomez, A. K. and Gomez, A. A. (1984). Statistical Procedure for Agricultural Research.John Wiley and Sons, Inc., London. 680pp.

Kamara, A. Y., Ekeleme, F., Kwari, J. D., Omoigui, L. O. and Chikoye, D. (2011a). Phosphorus effect on growth and yield of groundnut varieties in the tropical savanna of North Eastern Nigeria. J. of Tropical Africa, 49(2): 24 - 30.

Kamara, E. G.; Olympio, N.S. and Asibuo, J.Y. (2011b). Effect of calcium and phosphorus fertilizer on the growth and yield of groundnut (Arachis hypogaea L.). Int. Res. J. of Agri. Sci. and Soil Sci. (ISSN: 2251-0044), 1(8) pp. 326331.

Kwari, J. D. (2005). Soil Fertility Status in Some Communities of Southern Borno. PROSAB, Nigeria. 21pp.

Mahrous, N. M.; S. A. Safina; H.H. Abo Taleb and S. M. El-Behlak.(2015). Integrated use of organic, inorganic and bio fertilizers on yield and quality of two peanut (Arachis hypogaea L.) cultivars grown in a sandy saline soil. American-
Eurasian J. Agric. \& Environ. Sci., 15 (6): 1067-1074.

Meena, R.S, R.S; Yadav and V.S. Meena (2014). Response of groundnut (Arachis hypogaea L.) varieties to sowing dates and NP fertilizers under western dry zone of india. Bangladesh J. Bot. 43(2): 169-173.

Sarkees N.A. (2015). Effect of Sowing Dates on Development, Seed Yield and Quality of Some Peanut (Arachis hypogaea L.) Genotypes. Jordan J. Agric. Sci., 11(2): 67-380.

SAS institute (2008). The SAS System for Windows, release 9.2. Cary NC: SAS institute.

Sorrensen, R., Butts, C., Lamb, M. and Rowland, D. (2004). Five Years of Subsurface Drip Irrigation on Peanut.Research and Extension Bulletin No. 2004.

Taru, V. B., Khagya, I. Z., Mshelia, S. I. and Adebayo, E. F. (2008). Economic efficiency of resource use in groundnut production in Adamawa State of Nigeria.World Journal of Agricultural Science, 56: 4896 900.

Uma, M. N. and Sathiyavani, G. (2012). Solubilization of phosphate by Bacillus Sp., from groundnut rhizosphere (Arachis hypogaea L.). J. of Che. and Phar., Res. 4(8): 4007-4011.

Vara Prasad, P. V., VijayaGopal, K. and Hari, D. U. (2009). Growth and production of groundnut, in Soils, Plant Growth and Crop Production. In: Encyclopedia of Life Support Systems. (Ed. Willy H. V.), United Nations Education Scientific and Cultural Organization, Eolss. pp. $11-27$. 
استجابة بض التراكب الور اثيةمن الفول لسودلي الستويت التسميد الفوسفلي تحتظوف الودي الجدايد

احمد محمد احمد عبد المنعم' ومحمد ثروت سعيد` لجابل

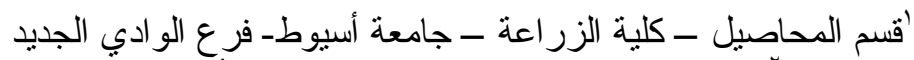

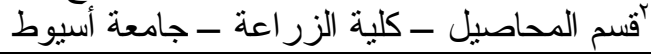

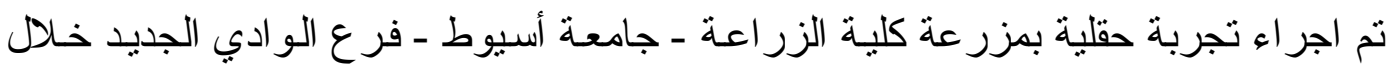

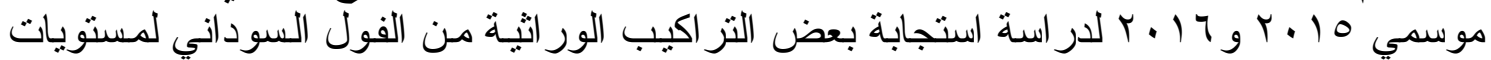

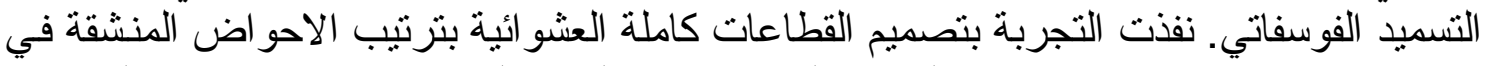

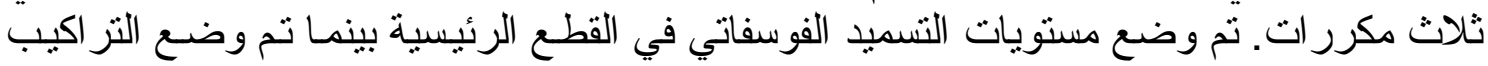

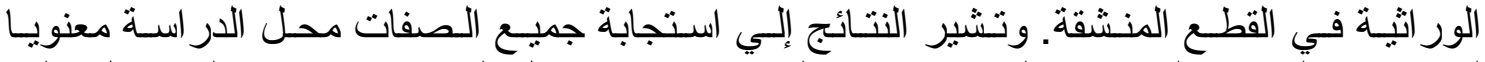

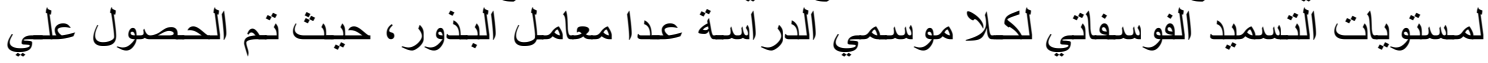

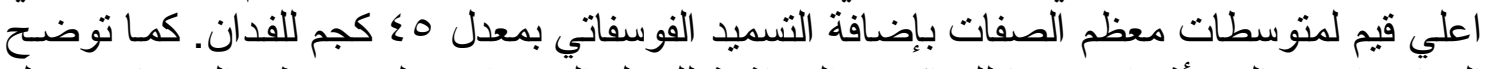

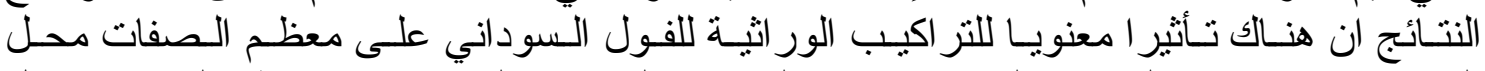

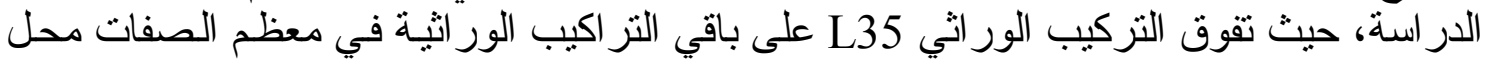

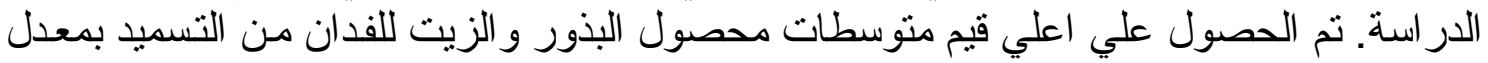

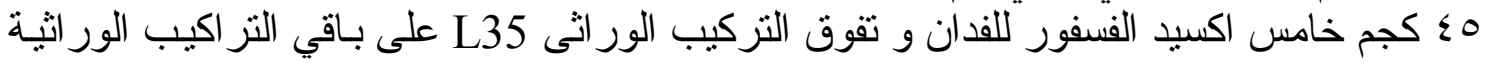
في محصول الزيت و البذور للفدان. 
Table 2. Effect of phosphorus fertilization levels and peanut genotypes on plant height and number of branches plant ${ }^{-1}$ in 2015 and 2016 seasons

\begin{tabular}{|c|c|c|c|c|c|c|c|c|c|}
\hline \multirow[t]{2}{*}{ Seasons } & \multirow[t]{2}{*}{ Genotype } & \multicolumn{4}{|c|}{$\begin{array}{l}\text { Plant height } \\
(\mathrm{cm})\end{array}$} & \multicolumn{4}{|c|}{ Number of branches plant ${ }^{-1}$} \\
\hline & & $\mathbf{P}_{15}$ & $\mathbf{P}_{30}$ & $\mathbf{P}_{45}$ & Mean & $\mathbf{P}_{15}$ & $\mathbf{P}_{30}$ & $\mathbf{P}_{45}$ & Mean \\
\hline \multirow{6}{*}{$\stackrel{n}{\stackrel{\sim}{\sim}}$} & $\mathrm{NC}$ & 28.89 & 36.22 & 37.44 & 34.18 & 8.22 & 8.11 & 9.00 & 8.44 \\
\hline & L3 & 31.22 & 36.22 & 39.11 & 35.52 & 8.44 & 8.78 & 9.78 & 9.00 \\
\hline & L10 & 26.56 & 29.00 & 35.34 & 30.30 & 6.78 & 7.89 & 9.11 & 7.93 \\
\hline & L35 & 27.89 & 36.56 & 38.89 & 34.45 & 8.11 & 8.33 & 10.67 & 9.04 \\
\hline & L27R & 28.00 & 33.44 & 34.78 & 32.07 & 8.45 & 9.56 & 11.00 & 9.67 \\
\hline & Mean & 28.51 & 34.29 & 37.11 & 33.30 & 8.00 & 8.53 & 9.91 & 8.82 \\
\hline \multicolumn{2}{|c|}{$\begin{array}{l}\text { Phosphorus } \\
\text { Genotypes } \\
\text { Phosphorus } \times \text { Genotypes }\end{array}$} & & & & & & & & \\
\hline \multirow{6}{*}{$\stackrel{0}{\stackrel{\sim}{\sim}}$} & $\mathrm{NC}$ & 30.78 & 33.89 & 35.44 & 33.37 & 7.22 & 8.22 & 8.56 & 8.00 \\
\hline & L3 & 32.67 & 36.00 & 38.56 & 35.74 & 8.78 & 9.11 & 9.22 & 9.04 \\
\hline & L10 & 31.59 & 32.33 & 37.89 & 33.94 & 7.22 & 8.33 & 10.11 & 8.55 \\
\hline & L35 & 30.11 & 35.56 & 39.11 & 34.93 & 7.45 & 8.67 & 10.56 & 8.89 \\
\hline & L27R & 29.34 & 34.11 & 34.89 & 32.78 & 9.11 & 9.33 & 10.89 & 9.78 \\
\hline & Mean & 30.90 & 34.38 & 37.18 & 34.15 & 7.96 & 8.73 & 9.87 & 8.85 \\
\hline \multicolumn{2}{|c|}{$\begin{array}{l}\text { Phosphorus } \\
\text { Genotypes } \\
\text { Phosphorus } \times \text { Genotypes }\end{array}$} & & & & & & & & \\
\hline
\end{tabular}

Table 3. Effect of phosphorus fertilization levels and peanut genotypes on pods number plant ${ }^{-1}$, pods weight plant ${ }^{-1}$, seed number plant ${ }^{-1}$, seed index and seed weight plant $^{-1}$ in 2015 and 2016 seasons

\begin{tabular}{|c|c|c|c|c|c|c|c|c|c|c|c|c|c|c|c|c|c|c|c|c|c|}
\hline \multirow[t]{2}{*}{ Seasons } & \multirow[t]{2}{*}{ Genotype } & \multicolumn{4}{|c|}{ Pods number plant ${ }^{-1}$} & \multicolumn{4}{|c|}{ Pods weight / plant } & \multicolumn{4}{|c|}{ Seed number plant ${ }^{-1}$} & \multicolumn{4}{|c|}{$\begin{array}{l}\text { Seed index } \\
\quad(\mathrm{gm})\end{array}$} & \multicolumn{4}{|c|}{ Seed weight plant $^{-1}$} \\
\hline & & $\mathbf{P}_{15}$ & $\mathbf{P}_{\mathbf{3 0}}$ & \begin{tabular}{|l|l}
$\mathbf{P}_{45}$ & 1 \\
\end{tabular} & Mean & $\mathbf{P}_{15}$ & $\mathbf{P}_{\mathbf{3 0}}$ & $\mathbf{P}_{45}$ & Mean & $\mathbf{P}_{15}$ & $\mathbf{P}_{\mathbf{3 0}}$ & $\mathbf{P}_{45}$ & Mean & $\mathbf{P}_{15}$ & $\mathbf{P}_{\mathbf{3 0}}$ & $\mathbf{P}_{45}$ & Mean & $P_{15}$ & $\mathbf{P}_{\mathbf{3 0}}$ & $\mathbf{P}_{45}$ & Mean \\
\hline \multirow{3}{*}{$\frac{n}{2}$} & L3 & 30.3 & 40.7 & 49.0 & 40.0 & 39.8 & 65.1 & 84.8 & 63.2 & 45.7 & 66.7 & 99.1 & 70.5 & 52.9 & 63.3 & 58.1 & 58.1 & 23.9 & 42.3 & 57.6 & 41.3 \\
\hline & L10 & 32.7 & 38.3 & \begin{tabular}{|l|}
44.7 \\
\end{tabular} & 38.6 & 27.9 & 55.1 & 72.0 & 51.7 & 33.0 & 58.8 & 72.6 & 54.8 & 57.0 & 63.1 & 67.9 & 62.7 & 18.6 & 37.5 & 49.6 & 35.2 \\
\hline & \begin{tabular}{|l|} 
L35 \\
\end{tabular} & 32.3 & 46.0 & 70.0 & 49.4 & 46.6 & 66.0 & 104.4 & 72.3 & 48.0 & 69.4 & 117.2 & \begin{tabular}{|l|}
78.2 \\
\end{tabular} & 68.3 & 66.0 & 60.9 & 65.1 & 32.9 & 45.8 & 71.2 & 50.0 \\
\hline & & \multicolumn{2}{|c|}{ F teste } & \multicolumn{2}{|c|}{ RLSD } & \multicolumn{2}{|c|}{ F teste } & \multicolumn{2}{|c|}{\begin{tabular}{|l|} 
RLSD \\
\end{tabular}} & \multicolumn{2}{|c|}{ F teste } & \multicolumn{2}{|c|}{ RLSD } & \multicolumn{2}{|c|}{ F teste } & \multicolumn{2}{|c|}{ RLSD } & \multicolumn{2}{|c|}{ F teste } & \multicolumn{2}{|c|}{ RLSD } \\
\hline \multicolumn{2}{|c|}{ Phosphorus } & \multicolumn{2}{|c|}{$* *$} & \multicolumn{2}{|c|}{4.5} & \multicolumn{2}{|c|}{$* *$} & \multicolumn{2}{|c|}{7.8} & \multicolumn{2}{|c|}{$* *$} & \multicolumn{2}{|c|}{7.1} & \multicolumn{2}{|c|}{ NS } & \multicolumn{2}{|c|}{---} & $*$ & $*$ & & .78 \\
\hline Gene & otypes & & $* *$ & & 2.8 & & k* & & .6 & & ** & 8. & .2 & & $*$ & & 83 & * & ;* & & .67 \\
\hline $\begin{array}{r}\text { Phosp } \\
\text { Geno }\end{array}$ & $\begin{array}{l}\text { horus } \times \\
\text { otypes }\end{array}$ & $*$ & $* *$ & & 5.1 & & $* *$ & & 3.1 & & $*$ & 15 & 5.6 & & JS & & -- & & $*$ & & 2.24 \\
\hline & L27R & 33.2 & 41.8 & 62.7 & 45.9 & 37.4 & 57.0 & 83.9 & 59.4 & 54.1 & 68.4 & \begin{tabular}{|l|}
93.7 \\
\end{tabular} & 72.1 & 49.8 & 57.2 & 63.6 & 56.9 & 26.2 & 39.0 & 58.7 & 41.3 \\
\hline & Mean & 32.1 & 41.6 & 54.4 & 42.7 & 51.0 & 62.7 & 86.3 & 66.7 & 53.1 & 65.3 & \begin{tabular}{|l|}
88.0 \\
\end{tabular} & 68.8 & 60.9 & 63.5 & 65.7 & 63.4 & 33.1 & 41.3 & 57.3 & 43.9 \\
\hline & & F te & este & & LSD & F t & este & RL & SD & $\mathbf{F t}$ & este & RL & SD & F te & este & & LSD & F te & este & & LSD \\
\hline Phos! & phorus & $*$ & $*$ & & 9.1 & & * & & 1.5 & & $*$ & 2 & 1 & & $\mathrm{JS}$ & & --- & & $*$ & & 5.58 \\
\hline Geno & otypes & $*$ & $*$ & & 3.4 & & $\mathrm{NS}$ & & -- & & $\mathrm{NS}$ & & -- & & $*$ & & .97 & $\mathrm{~N}$ & IS & & $\begin{array}{l}-- \\
\end{array}$ \\
\hline $\begin{array}{r}\text { Phosp } \\
\text { Geno }\end{array}$ & $\begin{array}{l}\text { horus } \times \\
\text { otypes }\end{array}$ & & $*$ & & 6.8 & & JS & & -- & & JS & & -- & & $* *$ & & .92 & $\mathrm{~N}$ & IS & & --- \\
\hline
\end{tabular}


Table 4. Effect of phosphorus fertilization levels and peanut genotypes on pods yield, seed yield, oil percentage and oil yield in 2015 and 2016 seasons

\begin{tabular}{|c|c|c|c|c|c|c|c|c|c|c|c|c|c|c|c|c|}
\hline \multirow[t]{2}{*}{ Seasons } & \multirow[t]{2}{*}{ Genotype } & \multicolumn{4}{|c|}{$\begin{array}{l}\text { Pods yield } \\
\text { (kg) }\end{array}$} & \multicolumn{3}{|c|}{$\begin{array}{l}\text { Seed yield } \\
(\mathrm{kg})\end{array}$} & \multicolumn{4}{|c|}{$\begin{array}{c}\text { Oil percentage } \\
(\%)\end{array}$} & \multicolumn{4}{|c|}{$\begin{array}{l}\text { Oil yield } \\
\text { (kg) }\end{array}$} \\
\hline & & $\mathbf{P}_{15}$ & $\mathbf{P}_{\mathbf{3 0}}$ & $\mathbf{P}_{45}$ & Mean & \begin{tabular}{|l|l|}
$\mathbf{P}_{\mathbf{1 5}}$ & $\mathbf{P}_{\mathbf{3 0}}$ \\
\end{tabular} & $\mathbf{P}_{45}$ & Mean & $P_{15}$ & $\mathbf{P}_{\mathbf{3 0}}$ & $\mathbf{P}_{45}$ & Mean & $\mathbf{P}_{\mathbf{1 5}}$ & $\mathbf{P}_{\mathbf{3 0}}$ & $\mathbf{P}_{45}$ & Mean \\
\hline \multirow{6}{*}{$\stackrel{\sim}{\stackrel{\sim}{二}}$} & $\mathrm{NC}$ & 874 & 1131 & 1305 & 1104 & \begin{tabular}{|l|l|}
489 & 653 \\
\end{tabular} & 782 & 641 & 43.5 & 46.1 & 47.8 & 45.8 & 2123 & 3023 & 372 & 295 \\
\hline & L3 & 1012 & 1236 & 1566 & 1271 & \begin{tabular}{|l|l|}
535 & 782 \\
\end{tabular} & 909 & 742 & 44.4 & 47.0 & 48.4 & 46.6 & 239 & 368 & 440 & 349 \\
\hline & L10 & 825 & 1206 & 1565 & 1199 & \begin{tabular}{|l|l|}
472 & 762 \\
\end{tabular} & 1064 & 766 & 43.7 & 47.8 & 47.6 & 46.3 & 2063 & 366 & 508 & 360 \\
\hline & L35 & 982 & 1327 & 1945 & 1418 & \begin{tabular}{|l|l|}
670 & 877 \\
\end{tabular} & 1184 & 910 & 44.3 & 45.1 & 47.1 & 45.5 & 296 & 3945 & 558 & 416 \\
\hline & L27R & 796 & 1004 & 1400 & 1067 & \begin{tabular}{|l|l|}
366 & 562 \\
\end{tabular} & 832 & 587 & 45.5 & 46.5 & 47.8 & 46.6 & 1672 & 2613 & 397 & 275 \\
\hline & Mean & 898 & 1181 & 1556 & 1212 & \begin{tabular}{|l|l|}
506 & 727 \\
\end{tabular} & 954 & 729 & 44.3 & 46.5 & 47.8 & 46.2 & 224 & 338 & 455 & 339 \\
\hline & & \multicolumn{2}{|c|}{ F teste } & \multicolumn{2}{|c|}{ RLSD } & F teste & \multicolumn{2}{|c|}{ RLSD } & F te & este & \multicolumn{2}{|c|}{ RLSD } & \multicolumn{3}{|c|}{ F teste } & RLSD \\
\hline \multicolumn{2}{|c|}{ Phosphorus } & \multicolumn{2}{|c|}{$* *$} & \multicolumn{2}{|c|}{87} & $* *$ & \multicolumn{2}{|c|}{95} & & * & \multicolumn{2}{|c|}{2.2} & \multicolumn{2}{|c|}{$* *$} & & 45 \\
\hline \multicolumn{2}{|c|}{ Genotypes } & \multicolumn{2}{|c|}{$* *$} & \multicolumn{2}{|c|}{87} & $* *$ & \multicolumn{2}{|c|}{76} & & vS & \multicolumn{2}{|c|}{---} & \multicolumn{2}{|c|}{$* *$} & & 39 \\
\hline \multicolumn{2}{|c|}{ Phosphorus $\times$ Genotypes } & \multicolumn{2}{|c|}{$* *$} & \multicolumn{2}{|c|}{177} & NS & \multicolumn{2}{|c|}{--- } & & $\mathrm{JS}$ & \multicolumn{2}{|c|}{---} & & NS & & --- \\
\hline & \begin{tabular}{|l|l|} 
NC \\
\end{tabular} & 781 & 1062 & 1487 & 1110 & \begin{tabular}{|l|l|}
460 & 632 \\
\end{tabular} & 965 & 686 & 42.8 & 48.1 & 45.2 & 45.3 & 198 & 304 & 439 & 313 \\
\hline & L3 & 964 & 1342 & 1609 & 1305 & \begin{tabular}{|l|l|}
567 & 836 \\
\end{tabular} & 1038 & 814 & 45.4 & 43.6 & 45.6 & 44.9 & 256 & 363 & 475 & 365 \\
\hline 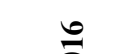 & L10 & 915 & 1091 & 1609 & 1205 & \begin{tabular}{|l|l|}
589 & 756 \\
\end{tabular} & 1140 & 828 & 45.9 & 45.6 & 43.6 & 45.0 & 270 & 345 & 498 & 371 \\
\hline ฮิ & L35 & 1025 & 1278 & 1755 & 1353 & \begin{tabular}{|l|l|}
750 & 894 \\
\end{tabular} & 1144 & 929 & 45.2 & 45.0 & 43.7 & 44.6 & 341 & \begin{tabular}{|l|l}
402 & 5 \\
\end{tabular} & 500 & 414 \\
\hline & L27R & 802 & 1000 & 1751 & 1184 & \begin{tabular}{|l|l|}
396 & 571 \\
\end{tabular} & 1104 & 690 & 48.0 & 48.5 & 44.6 & 47.0 & 190 & 277 & 492 & 319 \\
\hline & Mean & 897 & 1155 & 1642 & 1231 & \begin{tabular}{|l|l|}
552 & 738 \\
\end{tabular} & 1078 & 789 & 45.5 & 46.2 & 44.5 & 45.4 & 2513 & 338 & 481 & 357 \\
\hline & & F t & este & & LSD & F teste & & LSD & F te & este & & LSD & & teste & & RLSD \\
\hline Pho & sphorus & & $* *$ & & 16 & $* *$ & & 72 & & JS & & --- & & $* *$ & & 50 \\
\hline $\mathbf{G e}$ & lotypes & & $*$ & & 40 & $* *$ & & 89 & & * & & 1.5 & & $* *$ & & 39 \\
\hline Phosphort & I $\times$ Genotypes & & $\mathrm{JS}$ & & -- & NS & & - & & ** & & 2.6 & & NS & & --- \\
\hline
\end{tabular}

